\title{
Analisis isi buku teks geografi kelas XI SMA kurikulum 2013 (K13) edisi revisi terbitan Mediatama berdasarkan keterampilan abad 21
}

\author{
Retno Sarinastiti*, Yunus Aris Wibowo* \\ * Pendidikan Geografi, FKIP, Universitas Muhammadiyah Surakarta, Surakarta, \\ Indonesia
}

\begin{tabular}{l}
\hline \hline ARTICLES INFO \\
\hline Profil Articles: \\
Sent: $8-12-2020$ \\
Approved: $30-1-2021$ \\
Published: $30-1-2021$ \\
\hline
\end{tabular}

Key words:

Analisis isi; BSNP; keterampilan abad 21; geografi

\begin{abstract}
The purpose of this research was to analyze the suitability of the material in the Geography textbook for Class XI Curriculum 2013 published by Mediatama based on the BSNP Textbook Criteria and the completeness of the 21 st century (4C) skill components. This research uses qualitative research with a content analysis approach. The research subject used was the Geography textbook Class XI Curriculum 2013 Revised Edition published by Mediatama. The research subject was the Geography textbook for Class XI of the 2013 Curriculum, Revised Edition published by Mediatama. The data validity was done by triangulating the source. The research found that the books most used by the MGMP Sukoharjo were feasible $(87,61 \%)$. Based on the results of the analysis, according to the material expert, chapter I has the highest aspect is creative thinking and communication aspects ( $100 \%$ completeness), chapter III is critical thinking, creative thinking and communication (100\% completeness), chapter VII is critical and creative. think ( $100 \%$ complete). According to practitioners, chapter I is collaboration aspect (completeness 100\%), chapter III creative thinking (completeness 85.7\%), chapter VII critical thinking (completeness 89\%). According to researchers, chapter I is creative thinking, communication, and collaboration ( $100 \%$ complete), chapter III and chapter VII are $100 \%$.
\end{abstract}

ABSTRACT

Penelitian ini bertujuan untuk menganalisis kesesuaian materi dalam buku teks Geografi Kelas XI Kurikulum 2013 Terbitan Mediatama berdasarkan Kriteria Buku Teks BSNP dan kelengkapan komponen keterampilan abad 21 (4C). Sejalan dengan tujuan maka penelitain ini menggunakan jenis penelitian kualitatif dengan pendekatan analisis isi. Subjek penelitian yang digunakan adalah Buku teks Geografi Kelas XI Kurikulum 2013 Edisi Revisi terbitan Mediatama. Pengumpulan data dalam penelitian ini dilakukan dengan cara wawancara secara langsung dan instrumen penelitian berupa kuesioner untuk ahli materi dan praktisi pembelajar (guru). Keabsahan data dilakukan dengan triangulasi sumber. Hasil penelitian menunjukkan bahwa buku yang paling banyak digunakan MGMP Sukoharjo dikatakan layak digunakan (87.61\%). Berdasarkan analisis, menurut ahli materi bab I memiliki aspek tertinggi berfikir kreatif dan komunikasi (kelengkapan 100\%), bab III berpikir kritis, kreatif dan komunikasi (kelengkapan 100\%), bab VII berpikir kritis dan kreatif (kelengkapan $100 \%$ ). Menurut praktisi bab I memiliki aspek tertinggi kolaborasi (kelengkapan 100\%), bab III berpikir kreatif (kelengkapan 85,7\%), bab VII berpikir kritis (kelengkapan 89\%). Menurut peneliti bab I memiliki aspek tertinggi berpikir kreatif, komunikasi, dan kolaborasi (kelengkapan 100\%), bab III dan bab VII dikatakan bahwa semua keterampilan abad 21 memiliki kelengkapan 100\%.

This is an open access article under the CC-BY-SA license 
Jurnal Pendidikan Geografi:

Kajian, Teori, dan Praktik dalam Bidang Pendidikan dan Ilmu Geografi

Volume 26, Nomor 1, Januari 2021, Hal 48-60

\section{Correspondent Author:}

Retno Sarinastiti

Pendidikan Geografi

Universitas Muhammadiyah Surakarta

Jl. A. Yani, Mendungan, Pabelan, Kec. Kartasura, Surakarta, Jawa Tengah

E-mail: retnosari98.rs@gmail.com

\section{PENDAHULUAN}

Kemajuan teknologi yang sangat pesat membuat persaingan di dunia kerja semakin berat. Oleh karena itu, usaha untuk peningkatan mutu pendidikan menjadi hal penting yang harus diperhatikan. Diperlukan persiapan menuju peserta didik yang kreatif, novatif, dan kompetitif agar berfungsi efektif dalam teknologi yang sedang berkembang ini (Nkechinyere and Perpetua Ememe 2016). Kurikulum yang diperbaharui merupakan bentuk usaha dalam meningkatkan kualitas pendidikan dan menghadapi perkembangan zaman (Kusumam, Mukhidin, and Hasan 2016). Kurikulum 2013 diharapkan mampu membuat peserta didik memiliki pendidikan karakter dan keterampilan sebagaimana yang diharapkan. Sebuah keterampilan baru menjadi sangat penting di dunia modern saat ini (Laar et al. 2017). Penting untuk menjadikan generasi muda memiliki Keterampilan abad 21. Keterampilan abad 21 merupakan aset penting bagi para professional yang bekerja dalam industri kreatif (Laar et al. 2020). Kompetensi peserta didik yang dibutuhkan untuk menghadapi tantangan abad 21 ada empat kriteria (4C), yaitu Communication (komunikasi), Creativity and Innovation (berpikir kreatif dan inovatif), Critical Thinking and Problem Solving (berpikir kritis dan pemecahan masalah), dan Collaboration (Kolaborasi) (Kementerian Pendidikan dan Kebudayaan RI, 2017). Buku teks Kurikulum 2013 yang sesuai dengan kelayakan BSNP diharapkan dapat mendukung keterampilan abad 21.

Badan Standar Nasional Pendidikan yang selanjutnya disebut BSNP adalah badan mandiri dan independen yang bertugas mengembangkan, memantau pelaksanaan, dan mengevaluasi standar nasional pendidikan (Peraturan Pemeritah Nomor 19 Tahun 2005). Maka menjadi hal penting untuk mengetahui apakah buku layak digunakan berdasarkan kriteria BSNP atau tidak. Buku teks Kurikulum 2013 yang sesuai dengan kelayakan BSNP diharapkan dapat mendukung keterampilan abad 21. Kenyataannya buku teks yang beredar kebanyakan belum dapat dikatakan sesuai dengan Kurikulum 2013 maka diragukan kelayakannya berdasarkan BSNP dan tidak semuanya mampu menumbuhkan keterampilan berpikir kreatif, kritis, kolaborasi, dan komunikasi. Maka keterampilan yang telah diharapkan ada pada peserta didik tidak bisa tercapai (Yusliani et al., 2019). Hal ini menjadi penting untuk dikaji apakah buku yang digunakan selama ini sesuai dengan BSNP dan memuat keterampilan abad 21.

Salah satu mata pelajaran yang dipilih sebagai pendukung keterampilan abad 21 adalah Geografi. Geografi sebagai suatu disiplin yang turut mendukung dalam pendidikan yang berkelanjutan. Disiplin geografi juga terfragmentasi menjadi beberapa sub-disiplin, yakni geografi fisik, geografi manusia, biogeografi dan geografi ekonomi (Widener, Gliedt, and Ashlee 2016). Wilayah dengan konteks keruangan merupakan suatu sudut pandang geografi. Mata pelajaran geografi turut membantu mengembangkan kompetensi peserta didik menuju keterampilan abad 21 (Hidayat, 2019). Hal tersebut membuat mata pelajaran geografi menjadi salah satu yang mendukung terciptanya keterampilan abad 21.

Adanya temuan bahwa masih terdapat sekolah yang hanya mengacu pada ranah kognitif dan belum adanya kesesuaian antara buku mata pelajaran geografi dengan 
Jurnal Pendidikan Geografi:

Kajian, Teori, dan Praktik dalam Bidang Pendidikan dan Ilmu Geografi

Volume 26, Nomor 1, Januari 2021, Hal 48-60

keterampilan abad 21 (Hidayat, 2019). Hal tersebut juga yang melatarbelakangi mengapa buku geografi dipilih untuk penelitian. Buku geografi yang digunakan sebaiknya mampu membekali peserta didik untuk mengembangan keterampilan yang sesuai dengan tantangan abad ke 21. Seharusnya dalam mata pelajaran geografi objek formal dipadukan dalam penyajian objek material sehingga terciptanya pendekatan keruangan. Pendekatan keruangan inilah yang membedakan dengan kajian ilmu lain dan penciri khas bidang geografi (Saputra, 2015). Sebagai penciri khas geografi peserta didik dituntut untuk mampu memahami 1) kondisi lingkungan daerahnya dan mengenal betul tempat tinggalnya; 2) memahami fenomena alam yang ada di lingkungannya menggunakan peta; 3) memahami wilayah yang ditinggalinya dengan pengetahuan mitigasi yang baik (Nandi, 2016). Penelitian ini hanya mengkaji materi yang merupakan penunjang untuk meningkatkan pengetahuan geospasial. Analisis dilakukan untuk mengetahui bagaimana komponen keterampilan berpikir kritis, kreatif, komunikatif, dan kolaborasi dari sudut pandang geografi. Atas dasar tersebut maka yang akan dianalisis adalah materi "Kondisi wilayah dan posisi strategis Indonesia", "Persebaran dan pengelolaan sumberdaya alam", dan "Jenis dan penanggulangan bencana". Materi tersebut menunjukan posisi objek di permukaan bumi sehingga peserta didik mengenal posisi strategis Indonesia, karakteristik wilayah dan secara distribusi spasial diharapkan mampu mengetahui karakteristik bencana di suatu wilayah. Diharapkan dengan materi tersebut mampu menumbuhkan rasa cinta tanah air. Atas dasar pemikiran tersebut maka akan dilakukan analisis isi buku pada ketiga materi tersebut.

Berdasarkan ketarangan dari guru yang merupakan anggota MGMP dan merupakan guru geografi di SMAN 1 Kartasura, buku teks yang banyak digunakan untuk kegiatan belajar mengajar adalah buku terbitan Mediatama. Penelitian ini memfokuskan tentang analisis isi buku teks Geografi Kelas XI Kurikulum 2013 Edisi Revisi terbitan Mediatama untuk mengetahui kelayakan buku teks berdasarkan kriteria BSNP dan keterampilan abad 21. Penelitian ini bertujuan untuk menganalisis kesesuaian materi dalam buku teks Geografi Kelas XI Kurikulum 2013 Terbitan Mediatama berdasarkan kriteria buku teks BSNP dan kelengkapan komponen keterampilan abad 21 (4C).

\section{METODE}

Jenis penelitian yang digunakan dalam penelitian ini adalah kualitatif. Desain penelitian yang digunakan adalah analisis isi. Penelitian kualitatif ini digunakan untuk memahami suatu fenomena yang telah dialami oleh subjek penelitian seperti tindakan, perilaku, dan lain-lain secara deskrisi dan holistik melalui bahasa dan kata-kata dalam konteks khusus secara alamiah (Singestecia, Handoyo, and Isdaryanto 2018). Subyek penelitian ini adalah buku teks Geografi Kelas XI Kurikulum 2013 Edisi Revisi terbitan Mediatama. Objek Penelitian ini adalah isi buku geografi berdasarkan keterampilan abad 21 dan kelayakan buku berdasarkan BSNP. Instrumen penelitian yang digunakan dalam penelitian ini adalah kuesioner yang berisikan indikator keterampilan abad 21 dan Kelayakan BSNP.

Teknik analisis data yang digunakan pada penelitian ini adalah analisis isi. Subjek penelitian yang digunakan dalam penelitian ini adalah Buku teks Geografi Kelas XI Kurikulum 2013 Edisi Revisi terbitan Mediatama. Objek penelitian yang digunakan adalah Keterampilan abad 21 dan kelayakan buku berdasarkan BSNP. Analisis buku pada penelitian ini melibatkan tiga penilai yakni praktisi (praktisi), ahli materi, dan peneliti. Tahapan dalam menganalisis data terdiri dari (1) reduksi data yaitu memilihan, perhatian dengan penyederhanaan, pemusatan, dan transformasi yang terdapat di 
Jurnal Pendidikan Geografi:

Kajian, Teori, dan Praktik dalam Bidang Pendidikan dan Ilmu Geografi

Volume 26, Nomor 1, Januari 2021, Hal 48-60

lapangan; (2) penyajian data (display) yakni sekumpulan informasi yang sudah didapat dan telah tersusun sedemikian rupa yang memberi kemungkinan akan adanya penarikan kesimpulan disebut sebagai penyajian data; (3) penarikan kesimpulan yaitu menjabarkan pendapat-pendapat yang terakhir berdasarkan pada uaraian sebelumnya (Hardani et al. 2020).

Reduksi data dalam penelitian ini, dilakukan dengan memilah informasi yang telah didapatkan terkait buku, indikator kelayakan dan indikator keterampilan abad 21 . Informasi yang pertama didapatkan bahwa buku geografi yang banyak digunakan di Kabupaten Sukoharjo yakni buku geografi terbitan Mediatama Kurikulum 2013. Informasi kedua terdapat indikator keterampilan abad 21 yang dipaparkan oleh Badan Standar Nasional Pendidikan (BSNP) (Tabel 1). BSNP memberikan penilaian berupa kelayakan isi, bahasa, penyajian, dan kegrafikaan (BSNP 2014). Informasi ketiga didapatkan temuan bahwa Kementerian Pendidikan dan Kebudayaan juga memiliki indikator tersendiri terkait keterampilan abad 21 di Kurikulum 2013 (Tabel 2).

Indikator kelayakan buku menurut BSNP menunjukkan bahwa dalam menganalisis buku harus memperhatikan tatanan bahasa, isi, dan penyajian. Sebenarnya terdapat empat kriteria menurut BSNP yakni kelayakan isi, bahasa, penyajian, dan kegrafikaan. Penelitian ini hanya mengkaji bagian isi buku teks geografi, maka hanya menggunakan kriteria kelayakan isi, bahasa, dan penyajian. Setelah mengetahui indikator BSNP kemudian dilakukan pembuatan kuesioner untuk mempermudah dalam menganalisis ketiga bab. Kuesioner dibuat dengan memadukan antara indikator BSNP dengan indikator keterampilan abad 21. Terlihat bahwa indikator keterampilan abad 21 yang dipaparkan Kemendikbud mengandung banyak sub indikator keterampilan abad 21 (Tabel 2). Analisis dilakukan oleh tiga penilai yakni peneliti, ahli materi, dan praktisi. Saat menganalisis, sub indikator tersebut disajikan dalam bentuk kuesioner untuk mempermudah penilai (ahli materi, peneliti, dan praktisi) dalam menganalisis. Indikator Keterampilan Abad 21 pad Kurikulum 2013 disajikan pada Tabel 3.

Tabel 1. Indikator Penilaian Buku Berdasarkan BSNP

\begin{tabular}{clll}
\hline No & \multicolumn{1}{c}{ Kelayakan Bahasa } & \multicolumn{1}{c}{ Kelayakan Isi } & \multicolumn{1}{c}{ Kelayakan Penyajian } \\
\hline 1. & Lugas & $\begin{array}{l}\text { Kesesuaian materi dengan SK } \\
\text { dan KD }\end{array}$ & Pendukung penyajian \\
2. & $\begin{array}{l}\text { Komunikatif } \\
\text { Keakuratan materi }\end{array}$ & $\begin{array}{l}\text { Teknik penyajian } \\
\text { Kendukung materi pembelajaran } \\
\text { 3. }\end{array}$ & $\begin{array}{l}\text { Dialogis dan interaktif } \\
\text { alur pikir } \\
\text { Penyajian pembelajaran }\end{array}$ \\
& $\begin{array}{l}\text { Kesesuaian dengan perkem- } \\
\text { banagn peserta didik }\end{array}$ & Kemutakhiran materi & Pentan \\
\hline
\end{tabular}

Sumber: Badan Standar Nasional Pendidikan (2014)

Tabel 2. Persentase Kelayakan Buku Teks

\begin{tabular}{lll}
\hline Persentase (\%) & Kriteria/Predikat & Persentase (\%) \\
\hline $85-100$ & Sangat layak & $85-100$ \\
$65-84$ & Layak & $65-84$ \\
$55-64$ & Cukup Layak & $55-64$ \\
$40-54$ & Tidak Layak & $40-54$ \\
$0-39$ & Sangat Tidak Layak & $0-39$ \\
\hline
\end{tabular}

Sumber: BSNP DAN Pusat Pembukuan (2014) 
Jurnal Pendidikan Geografi:

Kajian, Teori, dan Praktik dalam Bidang Pendidikan dan Ilmu Geografi

Volume 26, Nomor 1, Januari 2021, Hal 48-60

Tabel 3. Indikator Keterampilan Abad 21 pada Kurikulum 2013

\begin{tabular}{|c|c|c|c|c|}
\hline No. & Berpikir Kritis & Berpikir Kreatif & Komunikasi & Kolaborasi \\
\hline 1. & $\begin{array}{l}\text { Mampu menggunakan } \\
\text { berbagai bentuk penalaran/ } \\
\text { tipe pemikiran atau alasan, } \\
\text { baik deduktif maupun } \\
\text { induktif dengan tepat dan } \\
\text { sesuai dengan situasi. }\end{array}$ & $\begin{array}{l}\text { Memiliki kemampuan } \\
\text { dalam melaksanakan, } \\
\text { mengembangkan, dan } \\
\text { menyampaikan gagasan- } \\
\text { gagasan baru secara lisan } \\
\text { atau tulisan. }\end{array}$ & $\begin{array}{l}\text { Mengelola, memahami } \\
\text { dan menciptakan suatu } \\
\text { komunikasi yang efektif } \\
\text { dalam berbagai bentuk } \\
\text { dan isi secara tulisan, } \\
\text { lisan dan multimedia } \\
\text { (ICT Literacy). }\end{array}$ & $\begin{array}{l}\text { Memiliki } \\
\text { kemampuan untuk } \\
\text { kerjasama } \\
\text { berkelompok. }\end{array}$ \\
\hline 2. & $\begin{array}{l}\text { Mampu memahami } \\
\text { interkoneksi antar satu } \\
\text { konsep dengan konsep yang } \\
\text { lainnya }\end{array}$ & $\begin{array}{l}\text { Mampu bersikap terbuka } \\
\text { serta responsif terhadap } \\
\text { perspektif baru dan } \\
\text { berbeda. }\end{array}$ & $\begin{array}{l}\text { Mampu menggunakan } \\
\text { kemampuan } \\
\text { mengutarakan ide- } \\
\text { idenya, baik itu saat } \\
\text { berdiskusi, di dalam dan } \\
\text { di luar kelas, maupun } \\
\text { tertuang pada tulisan. }\end{array}$ & $\begin{array}{l}\text { Mampu beradaptasi } \\
\text { dalam berbagai } \\
\text { peran dan } \\
\text { tanggungjawab serta } \\
\text { bekerja secara } \\
\text { produktif dengan } \\
\text { yang lain. }\end{array}$ \\
\hline 3. & $\begin{array}{l}\text { Melakukan penilaian dan } \\
\text { menentukan keputusan } \\
\text { secara efektif dalam } \\
\text { mengolah argumen dan } \\
\text { data. }\end{array}$ & $\begin{array}{l}\text { Mampu mengemukakan } \\
\text { ide-ide kreatif secara } \\
\text { praktikal dan konseptual. }\end{array}$ & $\begin{array}{l}\text { Mampu menggunakan } \\
\text { bahasa lisan yang sesuai } \\
\text { konten dan konteks } \\
\text { pembicaraan dengan } \\
\text { lawan bicara atau yang } \\
\text { sedang diajak } \\
\text { berkomunikasi. }\end{array}$ & $\begin{array}{l}\text { Memiliki rasa } \\
\text { empati dan } \\
\text { menghormati } \\
\text { perspektif yang } \\
\text { berbeda. }\end{array}$ \\
\hline 4. & $\begin{array}{l}\text { Mampu menguji hasil dan } \\
\text { membangun koneksi antara } \\
\text { informasi dan argument. }\end{array}$ & $\begin{array}{l}\text { Menggunakan konsep- } \\
\text { konsep / pengetahuannya } \\
\text { dalam situasi yang baru } \\
\text { dan berbeda, baik dalam } \\
\text { mata pelajaran terkait, } \\
\text { antar mata pelajaran, } \\
\text { ataupun dalam persoalan } \\
\text { kontekstual. }\end{array}$ & $\begin{array}{l}\text { Memiliki sikap } \\
\text { mendengarkan, } \\
\text { menghargai pendapat } \\
\text { orang lain selain } \\
\text { pengetahuan terkait } \\
\text { konten dan konteks } \\
\text { pembicaraan. }\end{array}$ & $\begin{array}{l}\text { Mampu } \\
\text { berkompromi } \\
\text { dengan anggota lain } \\
\text { dalam kelompoknya } \\
\text { demi tercapainya } \\
\text { tujuan yang telah } \\
\text { ditetapkan. }\end{array}$ \\
\hline 5. & $\begin{array}{l}\text { Mengolah dan } \\
\text { menginterpretasi informasi } \\
\text { yang didapat dari } \\
\text { kesimpulan awal dan } \\
\text { mengujinya dengan analisis } \\
\text { terbaik. }\end{array}$ & $\begin{array}{l}\text { Mampu menggunakan } \\
\text { kegagalan sebagai wahana } \\
\text { pembelajaran. }\end{array}$ & $\begin{array}{l}\text { Mamapu menggunakan } \\
\text { alur berpikir yang logis, } \\
\text { dan terstruktur sesuai } \\
\text { dengan kaidah yang } \\
\text { berlaku. }\end{array}$ & \\
\hline 6. & $\begin{array}{l}\text { Mampu membuat solusi } \\
\text { dari berbagai permasalahan } \\
\text { non-rutin, baik dengan cara } \\
\text { umum, maupun dengan } \\
\text { caranya sendiri. }\end{array}$ & $\begin{array}{l}\text { Memiliki kemampuan } \\
\text { dalam menciptakan } \\
\text { kebaharuan berdasarkan } \\
\text { pengetahuan awal yang } \\
\text { telah dimiliki. }\end{array}$ & $\begin{array}{l}\text { Keterampilan abad } 21 \\
\text { dalam kaitannya dengan } \\
\text { kemampuan } \\
\text { komunikasi, tidak } \\
\text { terbatas hanya pada satu } \\
\text { bahasa, tetapi } \\
\text { kemungkinan multi- } \\
\text { bahasa. }\end{array}$ & \\
\hline 7. & $\begin{array}{l}\text { Menggunakan kemampuan } \\
\text { yang dimiliki untuk } \\
\text { berusaha menyelesaikan } \\
\text { suatu permasalahan. }\end{array}$ & $\begin{array}{l}\text { Beradaptasi dalam situasi } \\
\text { yang baru dan memberikan } \\
\text { kontribusi positif terhadap } \\
\text { lingkungannya. }\end{array}$ & & \\
\hline 8. & $\begin{array}{l}\text { Menyusun, } \\
\text { mengungkapkan, } \\
\text { menganalisa, dan } \\
\text { menyelesaikan suatu } \\
\text { masalah. }\end{array}$ & & & \\
\hline
\end{tabular}

Sumber : Kementerian Pendidikan dan Kebudayaan (2017) 
Tahap kedua yakni penyajian data, penyajian data pada penelitian ini adalah mengolah dan menyajikan hasil analisis yang dilakukan oleh ahli materi, praktisi, dan peneliti. Penyajian data dilakukan dengan melihat kelayakan buku dan melihat perbedaan hasil analisis ketiga penilai terkait keterampilan abad 21. Penelitian ini membahas komponen keterampilan abad 21 yang paling banyak pada setiap bab dengan menyajikan diagram. Tahap ketiga yakni penarikan kesimpulan, penarikan kesimpulan yang dijabarkan yakni hasil akhir simpulan berdasarkan diagram yang disajikan.

\section{HASIL DAN PEMBAHASAN}

\section{Analisis Kelayakan Buku berdasarkan BSNP}

Kriteria kelayakan Badan Standar Nasional (BSNP) terdiri dari kelayakan penyajian, kelayakan bahasa, kelayakan isi, dan kegrafikaan (BSNP 2010). Penelitian ini tidak menganalisis kegrafikaan karena hanya menganalisis isi yang terkandung dalam buku. Kelayakan bahasa, kelayakan isi dan kelayakan penyajian (BSNP 2014). Berdasarkan hasil analisis yang dilakukan oleh ahli materi, praktisi dan peneliti, buku dikatakan layak digunakan (Gambar 1). Penilaian paling tinggi diberikan oleh ahli materi. Penilaian paling rendah diberikan oleh praktisi. Maka berdasarkan rata-rata buku sudah dikatakan sangat layak dengan persentase akhir ketiga bab yaitu $87,61 \%$.

Penelitian ini serupa dengan penelitian yang dilakukan oleh Sari et al (2012). Berdasarkan hasil pnelitian tersebut menunjukan bahwa buku yang paling banyak digunakan oleh MGMP dikatakan layak digunakan. Hasil dari analisis yang dilakukan penelitian ini membuktikan bahwa buku geografi yang banyak digunakan oleh MGMP kabupaten dinilai sesuai dan layak untuk digunakan dalam kegiatan belajar mengajar. Terutama buku yang memang disarankan oleh Pemerintah Kabupaten. Penelitian yang dilakukan oleh Yusliani, Burhan, \& Nafsih (2019) menyebutkan bahwa buku yang paling banyak digunakan pada kabupaten tertentu memiliki banyak komponen keterampilan abad 21 .

Kekurangan yang ada pada ketiga bab yang dianalisis ada pada pustaka yang digunkan. Berdasarkan hasil analisis oleh ahli materi, praktisi, dan peneliti dapat dikatakan bahwa ketiga bab kurang menunjang kebaharuan pustaka. Kemutakhiran pustaka dinilai kurang baik menurut praktisi, peneliti dan ahli materi. Hal ini bertolakbelakang dengan pernyataan menurut Praditha \& Lubis (2018) buku yang bagus sebaiknya memiliki kesesuaian pada fitur, contoh, dan rujukan. Sebaiknya menyajikan contoh-contoh yang sesuai atau relevan dengan keadaan saat ini dan memiliki rujukan terbaru.

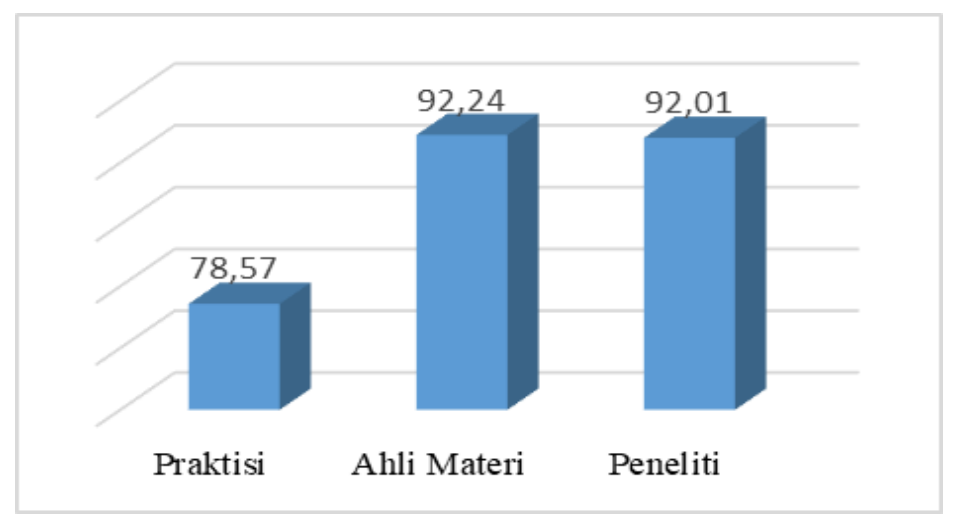

Gambar 1. Persentase Kelayakan Buku (\%) Sumber: Peneliti (2020) 
Penelitian ini serupa dengan penelitian yang dilakukan oleh Sari et al (2012). Berdasarkan hasil pnelitian tersebut menunjukan bahwa buku yang paling banyak digunakan oleh MGMP dikatakan layak digunakan. Hasil dari analisis yang dilakukan penelitian ini membuktikan bahwa buku geografi yang banyak digunakan oleh MGMP kabupaten dinilai sesuai dan layak untuk digunakan dalam kegiatan belajar mengajar. Terutama buku yang memang disarankan oleh Pemerintah Kabupaten. Penelitian yang dilakukan oleh Yusliani, Burhan, \& Nafsih (2019) menyebutkan bahwa buku yang paling banyak digunakan pada kabupaten tertentu memiliki banyak komponen keterampilan abad 21.

Kekurangan yang ada pada ketiga bab yang dianalisis ada pada pustaka yang digunkan. Berdasarkan hasil analisis oleh ahli materi, praktisi, dan peneliti dapat dikatakan bahwa ketiga bab kurang menunjang kebaharuan pustaka. Kemutakhiran pustaka dinilai kurang baik menurut praktisi, peneliti dan ahli materi. Hal ini bertolakbelakang dengan pernyataan menurut Praditha \& Lubis (2018) buku yang bagus sebaiknya memiliki kesesuaian pada fitur, contoh, dan rujukan. Sebaiknya menyajikan contoh-contoh yang sesuai atau relevan dengan keadaan saat ini dan memiliki rujukan terbaru.

\section{Analisis Komponen Keterampilan Abad 21 pada Buku Geografi}

Persentase dari keterampilan abad 21 pada Bab VII. Berdasarkan gambar terlihat perbedaan antara hasil analisis praktisi, ahli materi, dan peneliti. Indikator keterampilan abad 21 tertinggi ada pada "berpikir kritis" yang memiliki nilai rata-rata sebesar 96,33\%. Sementara terendah ada pada "kolaborasi" yakni memiliki nilai rata-rata hanya 91,66\% (Gambar 2). Peneliti memberikan nilai 100\% untuk keseluruhan keterampilan abad 21.

Persentase dari keterampilan abad 21 pada Bab III. Berdasarkan gambar terlihat perbedaan antara hasil analisis praktisi, ahli materi, dan peneliti. Indikator keterampilan abad 21 tertinggi ada pada "berpikir kreatif" dengan nilai rata-rata sebesar 95,23\%. Sementara terendah ada pada "kolaborasi" yakni memiliki nilai rata-rata hanya 91,66\% (Gambar 3). Peneliti memberikan nilai 100\% untuk keseluruhan keterampilan abad 21.

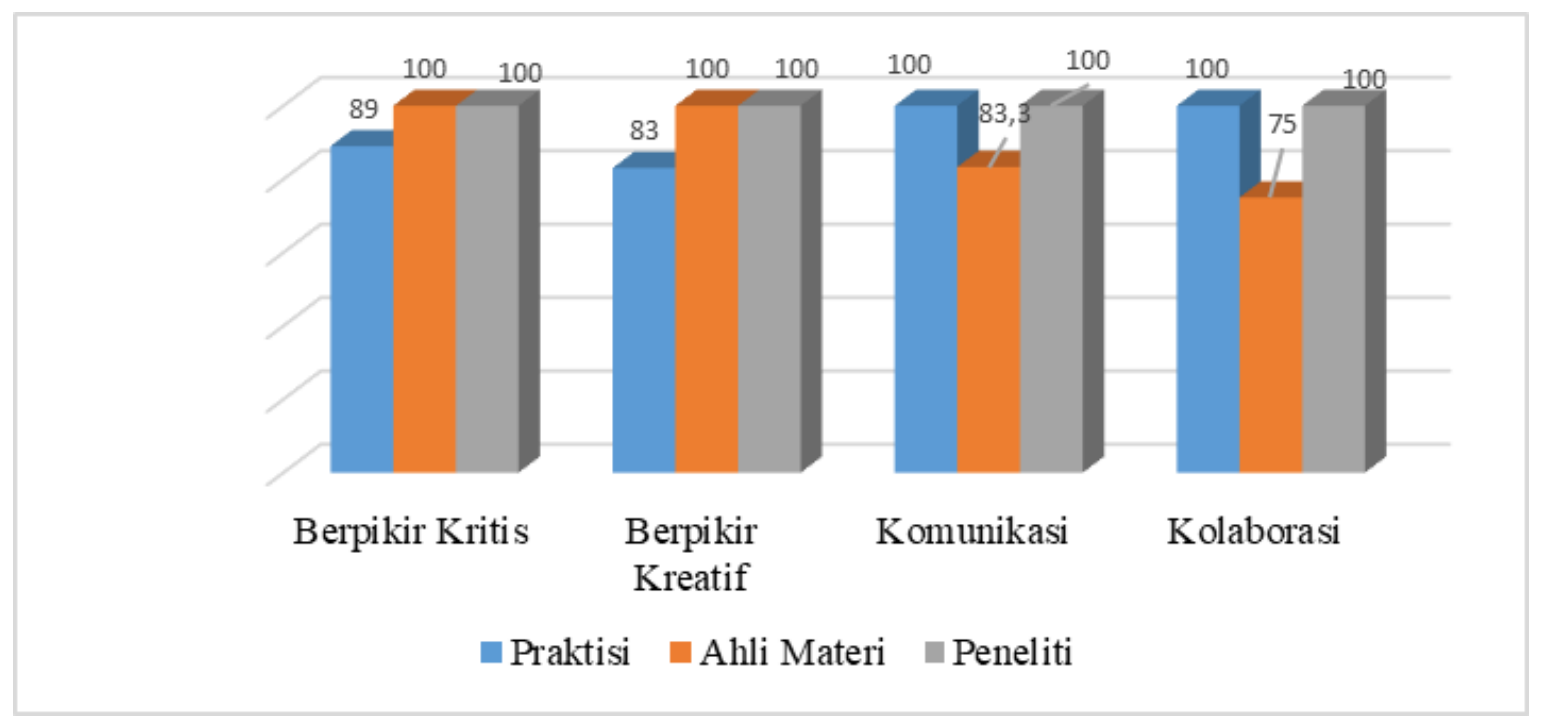

Gambar 2. Persentase Keterampilan Abad 21 Bab I (\%) Sumber: Peneliti (2020) 
Jurnal Pendidikan Geografi:

Kajian, Teori, dan Praktik dalam Bidang Pendidikan dan Ilmu Geografi

Volume 26, Nomor 1, Januari 2021, Hal 48-60

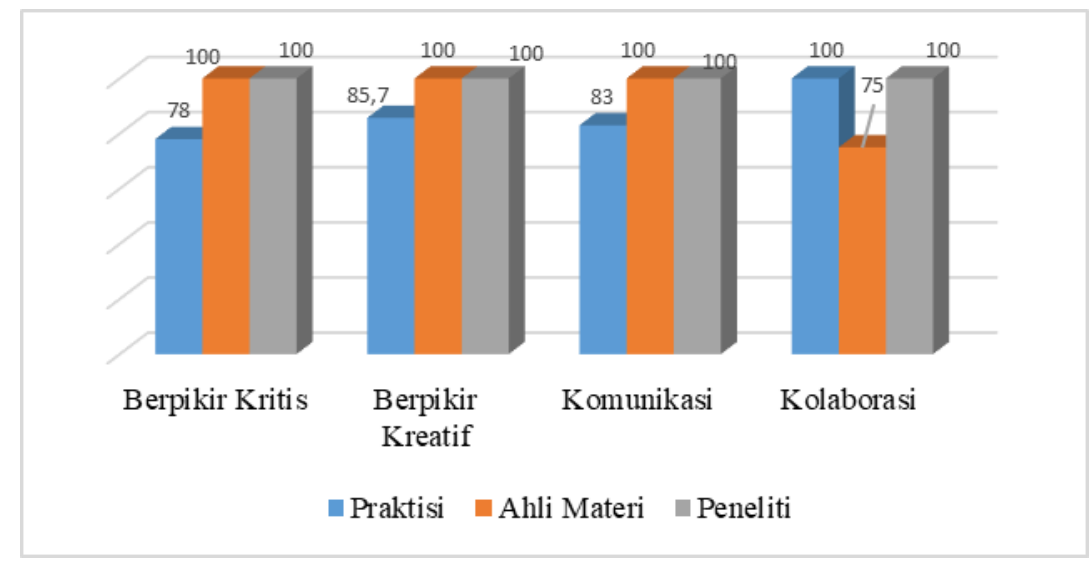

Gambar 3. Persentase Keterampilan Abad 21 Bab III (\%)

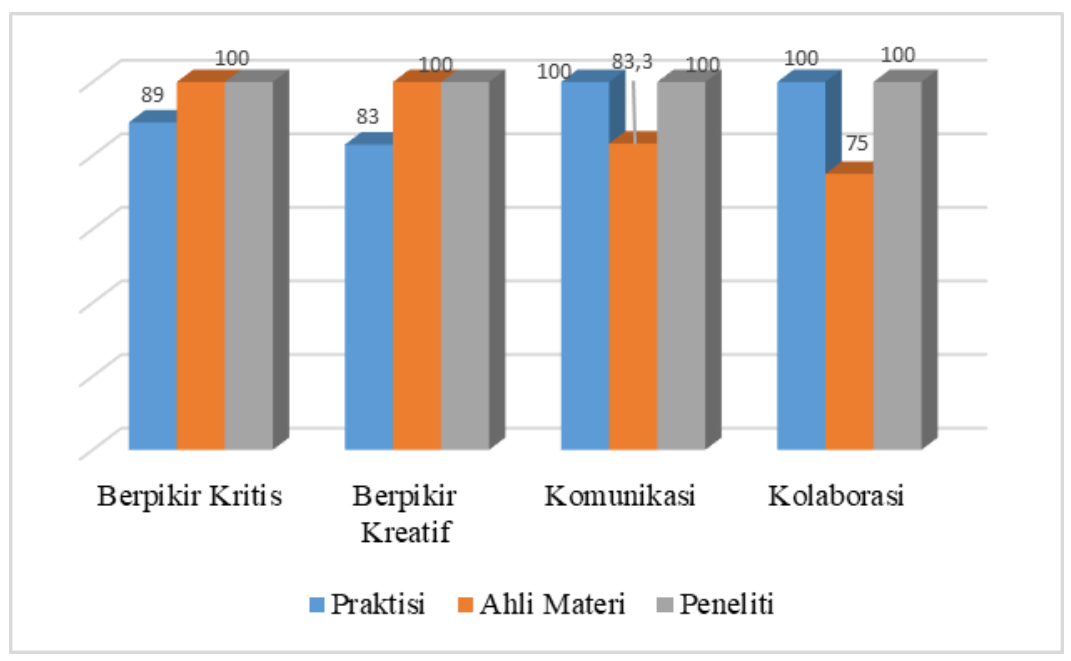

Gambar 4. Persentase Keterampilan Abad 21 Bab VII (\%)

Persentase dari keterampilan abad 21 pada Bab VII. Indikator keterampilan abad 21 tertinggi ada pada "berpikir kritis" yang memiliki nilai rata-rata sebesar 96,33\%. Sementara terendah ada pada "kolaborasi" yakni memiliki nilai rata-rata hanya 91,66\% (Gambar 4). Peneliti memberikan nilai 100\% untuk keseluruhan keterampilan abad 21.

Berdasarkan hasil analisis pada ketiga bab soal korelasi dianggap sebagai penunjang keterampilan berpikir kritis. Soal yang dimaksud yaitu berupa soal HOTS (Higher Order Thinking Skills) yang menyajikan materi penalaran yang mendalam (Gambar 5). Setiap bab pada buku geografi Mediatama setidaknya memiliki dua sampai lima soal HOTS serupa. Soal tersebut terdapat di bagian akhir pembahasan di setiap bab. Menurut peneliti, tipe soal semacam ini mampu mendukung peserta didik melatih logika dalam berpikir dan berpikir fkesibel. Peserta didik diharapkan akan lebih kritis dalam menanggapi dua hal yang berbeda dan menanggapi pernyataan. Hal ini sejalan dengan pernyataan menurut Lestari (2019) yaitu kegiatan menemukan, menanyakan, menganalisa, mengidentifikasi, dan merumuskan mampu meningkatkan intelektual siswa serta membuat pertimbangan dalam pengambilan keputusan. Menurut Kemendikbud 
Jurnal Pendidikan Geografi:

Kajian, Teori, dan Praktik dalam Bidang Pendidikan dan Ilmu Geografi

Volume 26, Nomor 1, Januari 2021, Hal 48-60

(2017) beberapa contoh dari berpikir kritis dan pemecahan masalah adalah menginterpretasi, menyelesaikan masalah, keterampilan dalam berpikir lebih tinggi (HOTS).

Berdasarkan hasil analisis, peta dianggap sebagai pendukung peserta didik memiliki keterampilan berpikir kreatif. Sebagai contoh salah satu peta yang dilengkapi oleh legenda dan unsur pendukung lainnya adalah "Peta Persebaran Barang Tambang di Indonesia" (Gambar 6). Peta tersebut menurut ahi materi mampu menunjukan keakuratan gambar dan terdapat kesesuaian dengan materi untuk melatih peserta didik mampu mengembangkan gagasan yang di milikinya. Menurut peneliti peta yang disajikan di setiap bab buku geografi Mediatama menunjukkan bentuk muka bumi terutama Indonesia dengan jelas dan berwarna. Pemilihan tampilan peta yang menyajikan tingkatan warna yang berbeda sehingga mampu mempermudah peserta didik menginterpretasikannya. Contoh yang diberikan ini merupakan sebuah gambaran pulaupulai Indonesia dan disajikan data persebaran bahan tambang. Diharapkan saat peserta didik melihat dengan jelas potensi di setiap daerah, mampu menunjang kreatifitas speserta didik dalam mengemukakan ide-ide mereka. Hal ini sejalan dengan pernyataan menurut Oktaviano (2017) konsep atau materi yang disajikan pada mata pelajaran geografi sebaiknya dilengkapi dengan contoh di dunia nyata. Peserta didik akan mengalami kebingungan apabila tidak disertai contoh dari dunia nyata maka penyajian contoh yang sesuai di dunia nyata dibutuhkan dalam pembelajaran geografi. Contoh materi dapat disajikan berupa virtual globe, peta lokasi atau tempat menggunakan data yang sebenar-benarnya dan nama yang sesungguhnya di lapangan. Menurut Zubaidah (2016) generasi muda hidup di dunia yang lebih menantang, sehingga diperlukannya suatu yang mendukung peserta didik memiliki pemikiran yang logis terhadap isu-isu penting yang kompleks. Harus disediakan peluang agar peserta didik mengembangkan kompetensi yang memungkinkan peserta didik mampu memahami situasi dan lingkungan.

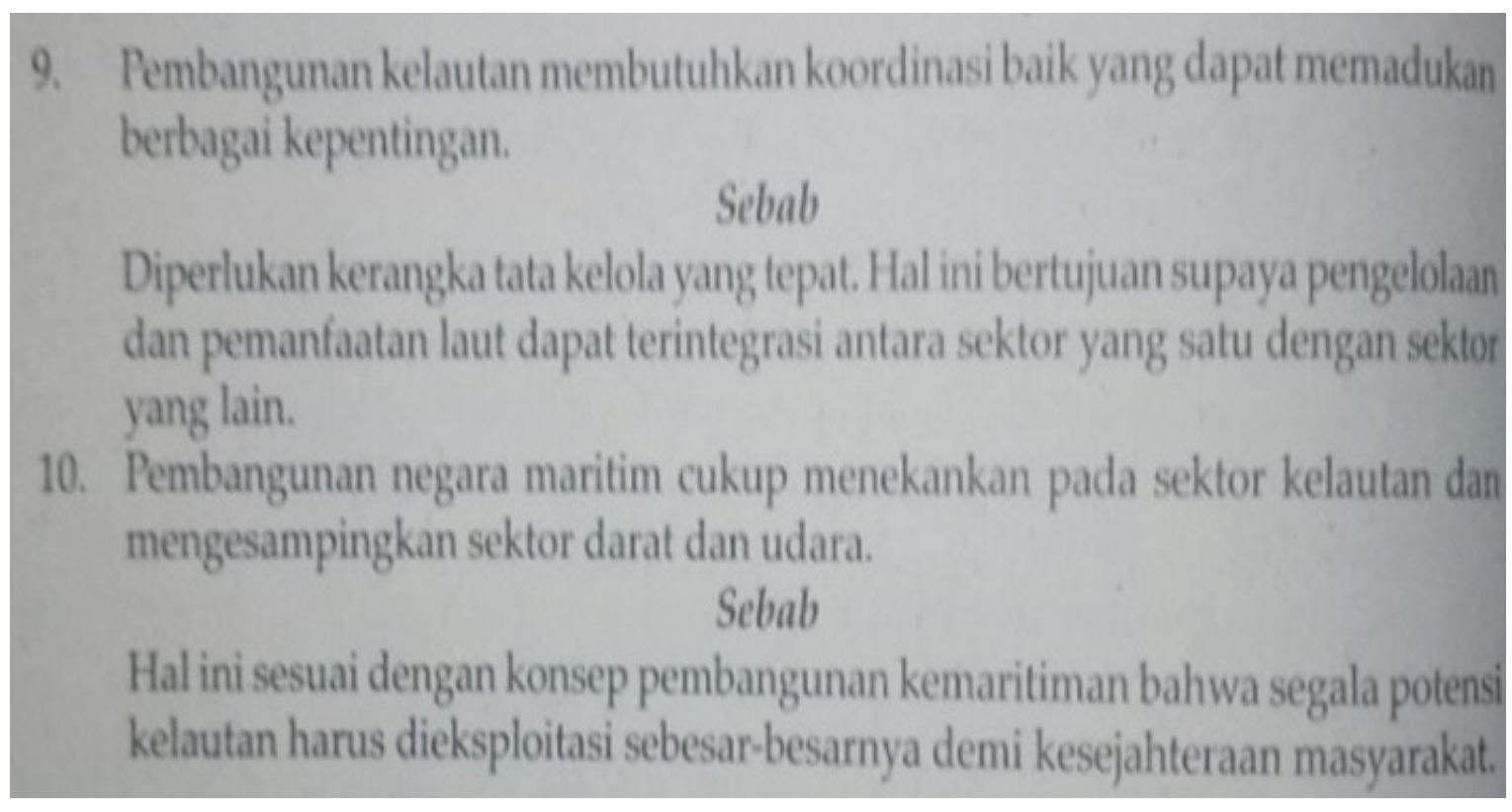

Gambar 5. Contoh Soal Korelasi

Sumber : Buku Geografi Kelas XI Terbitan Mediatama (2016) 


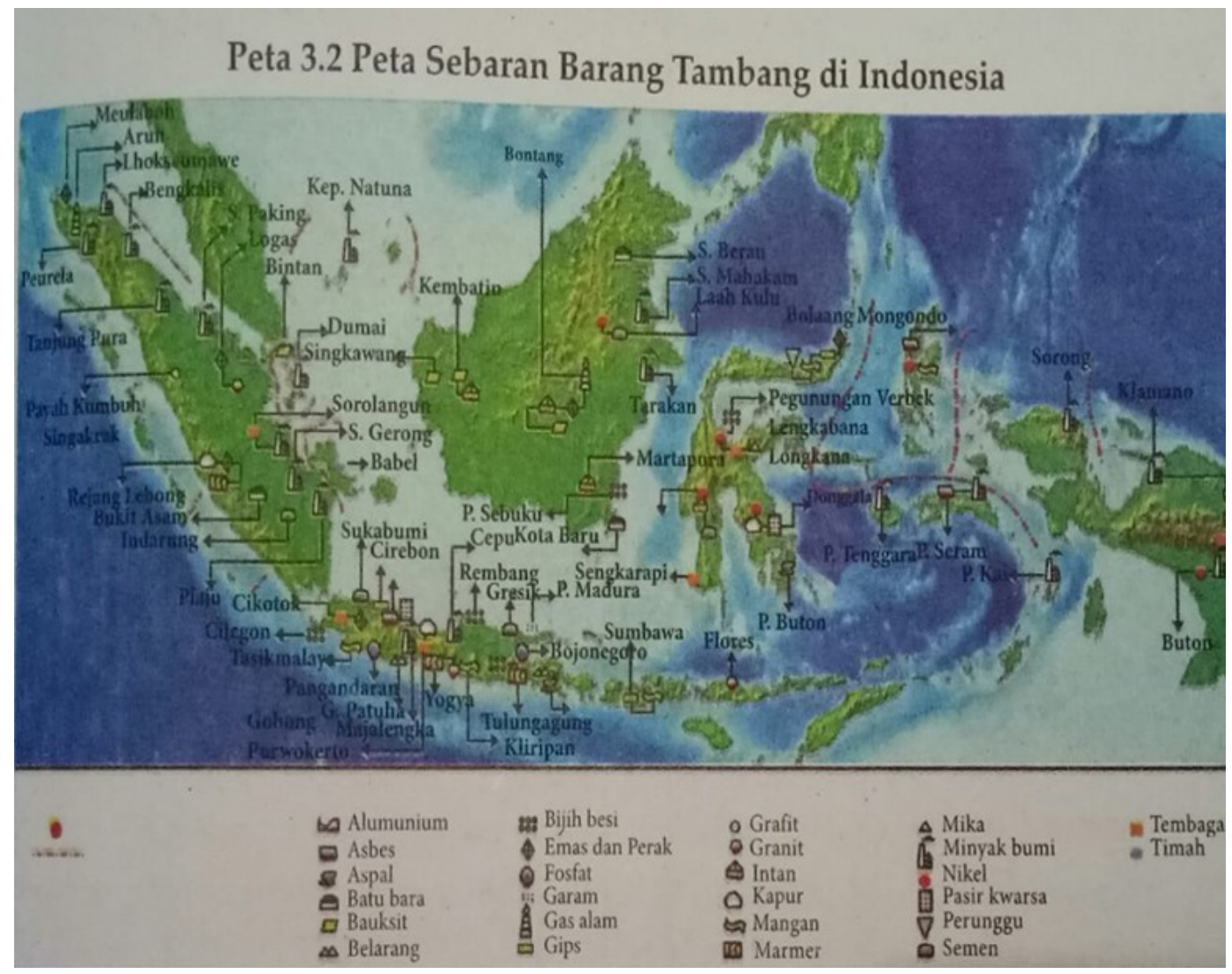

Gambar 6. Contoh Peta dan Legenda

Sumber : Buku Geografi Kelas XI Terbiatan Mediatama (2016)

Berdasarkan hasil analisis, poin yang dianggap sebagai pendukung peserta didik memiliki keterampilan komunikasi adalah kegiatan "diskusi kelompok" (Gambar 7). Menurut peneliti keterampilan komunikasi berupa kegiatan diskusi dianggap mampu melatih peserta didik mampu menyampaikan secara lisan ide-ide yang dimiliki kepada orang lain. Kegiatan "diskusi kelompok", diharapkan memiliki peran untuk meningkatkan kemampuan menggunakan bahasa lisan yang sesuai konten dan konteks pembicaraan. Buku geografi Mediatama di setiap bab mencantumkan kegiatan diskusi terbuka (Tanya jawab) sehingga mampu menunjang peserta didik memiliki sikap mendengarkan dan menghargai pendapat orang lain. Terdapat instruksi pada soal untuk melakukan tanya jawab kepada guru dan teman terkait identifikasi hasil yang telah didapat. Hal ini diharapkan mampu mendukung peserta didik memiliki keingintahuan lebih dengan saling bertanya dan mengemukakan pendapat. Hal ini sejalan dengan pernyataan menurut Nofrion (2018) menciptakan pembelajaran yang mampu membangkitkan kretivitas secara terus menerus dan membangkitkan keingintahuan siswa salah satunya harus memfasilitasi dan instruksi untuk peserta didik melakukan diskusi dan tanya jawab dalam menentukan prinsip, hokum, konsep, dan teori. Adanya instruksi membaca, mendengar, melihat, mencari informasi, mengamati fenomena secara langsung atau rekonstruksi. Adanya kebebasan untuk peserta didik melakukan presentasi menggunakan aplikasi baru yang terduga hingga tak terduga.

Berdasarkan hasil analisis, poin yang dianggap sebagai pendukung peserta didik memiliki keterampilan kolaborasi adalah "Muatan Aktivitas Peserta Didik" (Gambar 8). 
Jurnal Pendidikan Geografi:

Kajian, Teori, dan Praktik dalam Bidang Pendidikan dan Ilmu Geografi

Volume 26, Nomor 1, Januari 2021, Hal 48-60

Tugas berupa "Muatan Aktivitas Peserta Didik" tersaji di setiap bab buku geografi Mediatama. Tugas tersebut dibuat berdasarkan Permendikbud Nomor 8 Tahun 2016, hal ini menandakan bahwa tugas tersebut sudah sesuai dengan standar yang berlaku. Pemilihan poin ini sebagai pendukung keterampilan kolaborasi didasarkan pada penyajian aspek kolaborasi dan sesuai dengan Permendikbud. Diharapkan dengan adanya tugas tersebut peserta didik mampu bekerjasama, berkompromi dan bertanggung jawab dengan anggota kelompoknya. Menurut peneliti tugas tersebut mampu melatih peserta didik dalam beradaptasi dengan karakter teman-temannya dan menjalin kerjasama yang efektif. Hal ini sejalan dengan pernyataan menurut Bakrun (2018) Keterampilan Kolaborasi merupakan keterampilan untuk bekerjasama dengan kelompok, bertanggung jawab atas tugas dan menghargai kelompoknya. menurut Mariana (2020) demi meningkatkan kolaborasi, perlu memancing peserta didik untuk menggali informasi bersama teman-teman di kelas dan membangun makna dari apa yang dipelajari. Menurut Yusliani, Burhan, \& Nafsih (2019) menunjukkan kemampuan bekerja sama dengan kelompok secara efektif dan saling menghormati satu sama lain merupakan ciri seseorang memiliki keterampilan kolaborasi.

\section{Kegiatan 1.1}

\section{Judul Kegiatan : Mengidentifikasi Letak Indonesia}

Jenis Kegiatan : Tugas Kelompok

Tujuan Kegiatan : Peserta didik dapat menjelaskan letak Indonesia dengan tepat dan melaporkan simpulan letak Indonesia dengan peta.

Supaya dapat mengidentifikasi letak Indonesia, ikutilah langkah-langkah berikut.

1. Bagilah kelasmu menjadi 6-8 kelompok dengan tenang!

2. Perhatikan beberapa gambar mengenai letak Indonesia, baik letak absolut maupun letak relatif!

3. Bertanyalah kepada gurumu atau teman sekelas tentang letak absolut dan relatif!

4. Lakukan diskusi dengan anggota kelompokmu mengenai letak Indonesia yang terdiri atas berikut ini!

a. Kelebihan dan kekurangan letak Indonesia.

b. Pemanfaatan kelebihan letak Indonesia.

c. Cara mengatasi kekurangan letak Indonesia.

5. Berikan analisis sederhana dari hasil diskusimu tentang letak Indonesia! Cantumkan pula data dan fakta beserta sumbernya dalam bentuk tabel!

6. Majulah ke depan untuk melaporkan hasil kerja kelompok menggunakan peta!

Gambar 7. Contoh Aspek Diskusi

Sumber : Buku Geografi Kelas XI Terbiatan Mediatama (2016) 


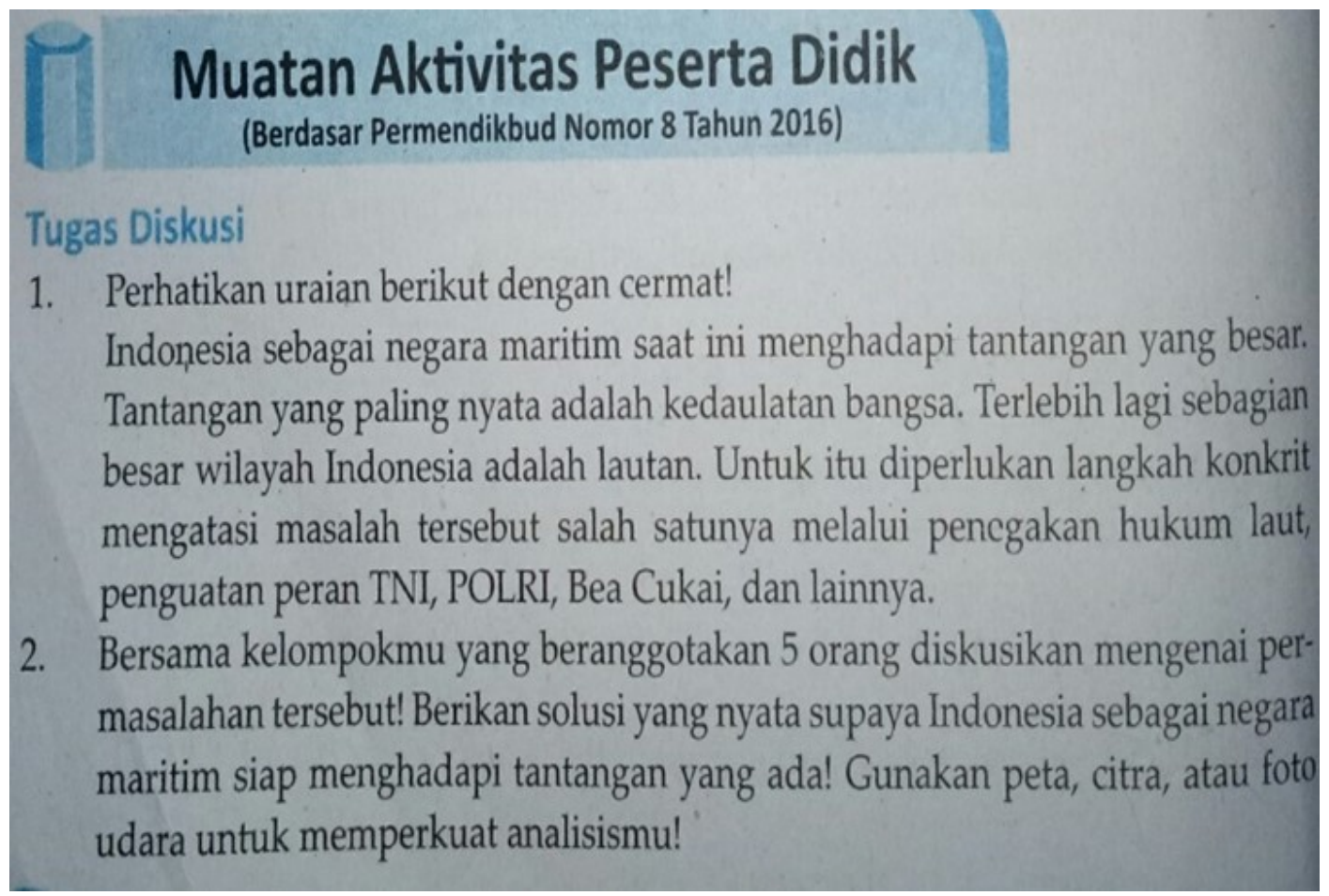

Gambar 8. Contoh Muatan Aktivitas Peserta Didik Sumber : Buku Geografi Kelas XI Terbiatan Mediatama (2016)

\section{KESIMPULAN}

Hasil penilaian kelayakan berdasarkan analisis didapatkan hasil bahwa ketiga bab tersebut sudah dikatakan sangat layak dengan persentase akhir ketiga bab yaitu 87,61\% setelah dilakukan perhitungan berdasarkan kriteria kelayakan BSNP. Isi yang terkandung dalam buku teks Geografi Kelas XI Kurikulum 2013 Edisi Revisi dikatakan sesuai dengan kriteria BSNP. Kelemahan dari buku hanya pada pustaka yang digunakan. Pustaka yang digunakan kurang up to date. Hasil analisis terkait kelengkapan komponen keterampilan abad 21 (kritis, kreatif, komunikasi, kolaborasi), pada ketiga bab yang dianalisis dikatakan sudah memiliki tingkat kelengkapan yang baik. Menurut analisis ahli materi, bab I memiliki tingkat kelengkapan sebesar 90,95\%, bab III sebesar 93,75\%, sedangkan bab VII sebesar 89,57\%. Bab I unggul pada aspek berfikir kreatif dan komunikasi, bab III unggul pada aspek berpikir kritis, kreatif, dan komunikasi, sementara bab VII unggul pada aspek berpikir kritis dan kreatif.

\section{DAFTAR RUJUKAN}

Arafat, Gusti Yasser. 2019. Membongkar isi pesan dan media dengan content analysis. Alhadharah: Jurnal Ilmu Dakwah 17(33):32.

BSNP. 2010. Laporan BSNP Tahun 2010. Jakarta.

BSNP. 2014. Lembar deskripsi instrumen buku siswa geografi.

BSNP dan Pusat Pembukuan. (2014). Instrumen penilaian tahap i dan tahap ii buku teks pelajaran pendidikan dasar dan menengah. http://bsnp-indonesia.org/?=1340

Hardani, Nur Hikmatul Auliya, Helmina Andriani, Roushandi Asri Fardani, Jumari Ustiawaty, Evi Fatmi Utami, Dhika Juliana Sukmana, and Ria Rahmatul Istiqamah. 
2020. Buku metode penelitian kualitatif \& kuantitatif. Yogyakarta: CV. Pustaka Ilmu Group Yogyakarta.

Kementerian Pendidikan dan Kebudayaan RI. 2016. Standar isi pendidikan dasar dan menengah. Jakarta: Bagian Hukum Kepegawaian.

Kementerian Pendidikan dan Kebudayaan RI. 2017. Panduan implementasi kecakapan abad 21 kurikulum 2013 di sekolah menengah atas. Jakarta.

Kusumam, Aliangga, Mukhidin, and Bachtiar Hasan. 2016. Pengembangan bahan ajar mata pelajaran. Jurnal Pendidikan Teknologi Dan Kejuruan 23(1):28-39.

Laar, Ester Van, Alexander J. A. M. Van Deursen, Jan A. G. M. Van Dijk, and Jos De Haan. 2017. The relation between 21 st-century skills and digital skills or literacy: a systematic literature review. Computers in Human Behavior 1:1-42.

Laar, Ester Van, Alexander J. A. M. Van Deursen, Jan A. G. M. Van Dijk, and Jos De Haan. 2020. Poetics measuring the levels of 21st-century digital skills among professionals working within the creative industries: A performance-based approach. Poetics (April 2019):101434.

Nkechinyere, Martha, and Amadi Perpetua Ememe. 2016. Rethinking higher education curriculum in Nigeria to meet global challenges in the 21 st century. The Development Of Higher Education in Africa: Prospeets and Challenges 21:459-83.

Peraturan Pemeritah. 2005. Standar nasional pendidikan. Jakarta.

Saputra, Yulian Widya. 2015. Pengembangan bahan ajar geografi pada kompetensi dasar memahami atmosfer dan dampaknya terhadap kehidupan di muka bumi kelas $\mathrm{X}$ SMA/MA semester II dengan menggunakan pendekatan keruangan. Jurnal Pendidikan Geografi 20 (2):53-60.

Sari, Eka Anjar, R. Sugiyanto, Heri Tjahjono, and Info Artikel. 2012. Penilaian kualitas buku teks pelajaran geografi sebagai sumber belajar bagi siswa SMA kelas XI di Kabupaten Temanggung. Edu Geography 1(1).

Singestecia, Regina, Eko Handoyo, and Noorocmat Isdaryanto. 2018. Partisipasi politik masyarakat Tionghoa dalam pemilihan kepala daerah di Slawi Kabupaten Tegal. JPPUMA: Jurnal Ilmu Pemerintahan Dan Sosial Politik UMA (Journal of Governance and Political Social UMA) 2(1):63-72.

Widener, Jeffrey M., Travis Gliedt, and Tziganuk Ashlee. 2016. Assessing sustainability teaching and learning in geography education. International Journal of Sustainability in Higher Education 17(5):1-34.

Widodo, Arif, Dyah Indraswati, and Muhammad Sobri. 2019. Analisis nilai-nilai kecakapan abad 21 dalam buku siswa SD/MI kelas V sub bab tema 1 manusia dan lingkungan. Jurnal Ilmiah Kependidikan 8(2):125-33.

Yusliani, Erlina, Hanana Laila Burhan, and Nurul Zakiatin Nafsih. 2019. Analisis integrasi keterampilan abad ke-21 dalam sajian buku teks fisika SMA kelas XII semester 1. Jurnal Eksakta Pendidikan (JEP) 3(November):184-91. 